\title{
Effects of temperature on the reproduction type of Scolionema suvaense living on seaweed and seagrass
}

\author{
Hiroki Kayashima, Shoko Tanabe, Yumiko Kakihara \& Haruto Ishiı* \\ Tokyo University of Marine Science and Technology, 4-5-7 Konan, Minato-ku, Tokyo, 108-8477, Japan
}

Received 16 May 2018; Accepted 12 November 2018 Responsible Editor: Dhugal Lindsay

doi: $10.3800 /$ pbr. 14.55

\begin{abstract}
Scolionema suvaense is a medusa belonging to the order Limnomedusae, and commonly lives on seaweed and seagrass. The benthic polyp and planktonic medusa are both stages of the life cycle of S. suvaense. Most of the planulae produced by sexual reproduction by the medusae do not metamorphose into polyps but to motile frustules moving to the bottom, which then metamorphose into polyps. The polyps can asexually produce not only medusae but also motile frustules. At a low temperature $\left(15^{\circ} \mathrm{C}\right)$, polyps mostly asexually produce frustules. Extension of the habitat area by motile frustules is suggested to occur during winter and early spring when the temperatures are low. With increasing temperature, the reproduction type of $S$. suvaense polyps changes to asexual production of medusae. In the medusa stage, $S$. suvaense can reproduce both sexually and asexually. The relative percentages of asexually-reproducing medusae vs. sexually-reproducing medusae were highest at $20^{\circ} \mathrm{C}$. This coincides with the highest abundance recorded for $S$. suvaense medusae, which showed an abrupt increase between May and June. Moreover, with increasing temperature (over $25^{\circ} \mathrm{C}$ ), the reproductive mode of $S$. suvaense medusae changes from asexual to sexual, and asexually reproducing medusae are not observed at such high temperatures. Changes in the reproduction type and fluctuations in the subsequent population dynamics of $S$. suvaense depend on the in situ temperatures.
\end{abstract}

Key words: reproduction, polyp, frustule, Scolionema, seaweed and seagrass

\section{Introduction}

Scolionema suvaense (Agassiz \& Mayer, 1899) is a medusa belonging to the family Limnomedusae Kramp, 1938, commonly living on seaweed and seagrass, e.g., Zostera marina Linnaeus, 1753 and Sargassum confusum C. Agardh, 1824 (Goy 1973). Along the European coast, S. suvaense is observed from May to October in the Bay of Villefranche-sur-mer (France) (Goy 1973); this species is also observed along the coast of Japan from May to July (Toyokawa 2003). The life cycle of S. suvaense has both benthic polyp and planktonic medusa stages (Goy 1973, Uchida \& Sugiura 1976). Specifically, in the medusa stage, $S$. suvaense reproduces both sexually and asexually (Uchida \& Sugiura 1976). Other hydrozoans that asexually reproduce in the medusa stage include Rathkea octopunctata (M. Sars, 1835) (Berrill 1952), Corymorpha gemmifera (Bouillon, 1978) (Kawamura \& Kubota

\footnotetext{
*Corresponding author: Haruto Ishii; E-mail, ishii@kaiyodai.ac.jp
}

2005), Podocorynoides minima (Trinci, 1903) (Uchida \& Sugiura 1977, Chaplygina \& Dautova 2005), Proboscidactyla ornata (McCrady, 1859) (Uchida \& Sugiura 1975, Kawamura \& Kubota 2008), Climacocodon ikarii Uchida, 1924 (Kubota 1993), Eucheilota paradoxica Mayer, 1900 (Carré \& Carré 1990), Sugiura chengshanense (Ling, 1937) (Sugiura 1973), and Aequorea macrodactyla (Brandt, 1835) (Stretch \& King 1980). In the polyp stage of members of the genus Scolionema, S. suvaense and Scolionema sanshin Toshino, 2017 (Toshino 2017) can asexually produce not only medusae but also frustules. Other limnomedusan species that can produce frustules in the polyp stage include Craspedacusta sowerbii Lankester, 1880 (Matthews 1966) and Gonionemus vertens A. Agassiz, 1862 (Uchida 1976). Their population easily increases by asexual reproduction, and is thus an important regulator for the abundance of this species. However, the life cycle of $S$. suvaense and the relationship between its reproduction type and population dynamics have not been studied in detail. Furthermore, studies on the population dynamics of $S$. suvaense in Japan are very limited (Toyokawa et al. 
2003). Moreover, studies related to the life cycles of species living on seaweeds and seagrasses such as S. suvaense are also lacking compared with those related to the life cycle of planktonic jellyfish such as Aurelia coerulea von Lendenfeld, 1884 (Möller 1980, Omori et al. 1995). Some species such as $G$. vertens, living on seaweed and seagrass, are known to sting fishermen or swimmers (Toyokawa 2003); hence, it is also important to shed light on the life cycle of these jellyfish species.

This study aimed to elucidate seasonal changes in the population dynamics of Scolionema suvaense and to determine the relationship between the reproduction type and population dynamics of $S$. suvaense, considering environmental factors such as temperature.

\section{Materials and Methods}

\section{Field surveys and sampling}

Sampling of Scolionema suvaense medusae was conducted at the ebb tide during daytime every 2 days from April 11 to July 31, 2016 at the Zostera marina area $\left(3996 \mathrm{~m}^{2}\right)$ at Nagai, Yokosuka, Kanagawa Prefecture. Nagai is situated on the west coast of the Miura Peninsula, and seagrass beds of $Z$. marina are frequently observed around this area. Hand nets $(40-\mathrm{cm}$ diameter and $1-\mathrm{mm}$ mesh size) were used to scoop up the medusae attached to $Z$. marina. After drawing the seagrass through the hand net, the presence of medusae in the hand net was checked by eye. Sampling of medusae was conducted over the whole extent of seagrasses in the area. Surface temperature and salinity were simultaneously measured. The collected medusae were immediately transferred with a pipette or spoon to a glass bottle $(900 \mathrm{~mL})$ filled with ambient seawater and then carried to the laboratory at the Tokyo University of Marine Science and Technology.

In the laboratory, the medusae in the glass bottles were transferred to a plastic bowl $(1.9 \mathrm{~L})$. For the incubation of Scolionema suvaense, $1 \mu \mathrm{m}$ filtered seawater was used. The number of medusae were counted while transferring with a pipette to multi-well plates (6 wells, 1 individual in each well), and the abundance at the sampling site was determined. The sex and maturity of medusa were determined using a stereomicroscope (Nikon SMZ1500). The gonads were observed in the center of the radial canals. The male gonad was ribbon-shaped and white and the female one was slightly longer and pinkish (personal observation, Goy 1973). Thirteen male medusae and nineteen female medusae were collected from the multi-well plates on June 19, 2016 and transferred to three plastic dishes ( $250 \mathrm{~mL}$ ) filled with $0.5 \mu \mathrm{m}$ filtered seawater for sexual reproduction experiments.

\section{Sexual reproduction experiment}

32 mature medusae in three plastic dishes were incubated at $25^{\circ} \mathrm{C}$ and a salinity of 33 under 12-h light/12- $\mathrm{h}$ dark conditions (10W fluorescent light). After $24 \mathrm{~h}$, all medusae were removed from the three plastic dishes, and the fertilized eggs and planulae were filtered through a $25 \mu \mathrm{m}$ mesh net; these were then transferred to a glass dish $(50 \mathrm{~mL})$ filled with filtered seawater. The number of eggs and planulae was counted using the stereomicroscope. The eggs and planulae in the glass dish were incubated at $25^{\circ} \mathrm{C}$. After 5 days, the number of planulae settled on each glass dish was counted using the stereomicroscope (Nikon SMZ1500).

\section{Asexual reproduction experiment (polyps)}

Polyps used for the experiments were obtained from the Sumida Aquarium, and originated from medusae collected at the Nagai area in the spring of 2014. Eight plastic dishes filled with $1 \mu \mathrm{m}$ filtered seawater $(250 \mathrm{~mL})$ and containing 3-5 polyps each were used. After the polyps were acclimated for a week at each temperature $\left(10^{\circ} \mathrm{C}, 15^{\circ} \mathrm{C}, 20^{\circ} \mathrm{C}\right.$, and $25^{\circ} \mathrm{C}$ ) under dark conditions, all frustules and medusae asexually produced by polyps were removed. Salinity of incubation seawater was 33. Artemia nauplii were supplied as food every 2 days.

Asexual reproduction experiments with polyps continued for 38 days. Artemia nauplii were supplied as food every 2 days, and the seawater in the plastic dishes was replaced with newly filtered seawater $1 \mu \mathrm{m}$ after $2 \mathrm{~h}$. Each plastic dish was incubated under the same conditions. The number of reproduced frustules and medusae was visually counted every 2 days. The stages with medusa buds on the polyps and the diameter of the liberated medusae were also determined. Stages with medusa buds on the polyps were determined based on photographs taken by a digital camera using the stereomicroscope. The bell diameter of the liberated medusae was measured using graph paper $(1 \times 1 \mathrm{~mm})$ placed under the plastic dishes. After the determination of the number of reproduced frustules and medusae, they were removed from incubation in the plastic dishes. Only medusae incubated at $20^{\circ} \mathrm{C}$ were used for the asexual reproduction experiment. The medusae were transferred to transparent plastic cases $(50 \mathrm{~mL})$ filled with filtered seawater.

\section{Asexual reproduction experiment (medusae)}

Figure 1 shows the number of reproduced medusae used for the experiment and the name of each generation of asexually produced medusae. The maximum number of medusae used for the experiments are also indicated in this figure.

The medusae were incubated at $15^{\circ} \mathrm{C}, 20^{\circ} \mathrm{C}$, and $25^{\circ} \mathrm{C}$ in the transparent plastic cases $(50 \mathrm{~mL})$ filled with $1 \mu \mathrm{m}$ filtered seawater. The number of asexually reproduced medusae (daughter medusae) and the bell diameter of the medusae were determined every 2 days. The bell diameters of all medusae were measured using graph paper $(1 \times 1 \mathrm{~mm})$ placed under the transparent plastic cases. Four newlyreproduced daughter medusae in each transparent plastic 


Sirst medusa
$(\mathrm{M} 1)$
$(\mathrm{M} 2)$

Fig. 1. The number of medusae from each generation used for the asexual reproduction experiments, and the names of each generation of asexually-reproduced medusae. The maximum number of medusae used for the experiments are also indicated.

case were transferred to another transparent plastic case that was filled with filtered seawater, and the residual medusae were discarded. These four medusae in each transparent plastic case, along with the original medusae, were then incubated under the same conditions. Artemia nauplii were supplied as food for all medusae every 2 days, and the seawater in the transparent plastic cases was replaced with newly-filtered seawater after $2 \mathrm{~h}$. Each transparent plastic case was incubated under the same conditions. Gonad development in medusae was also determined using the stereomicroscope. The experiments were continued until all medusae were dead.

\section{Results}

Figure 2 shows the surface temperature, salinity, abundance, and maturity of Scolionema suvaense medusae versus date. The minimum and maximum temperatures were $19.1^{\circ} \mathrm{C}$ and $31.4^{\circ} \mathrm{C}$ on April 11 and July 19, respectively. Mean salinity was $32 \pm 2$, and significant differences were not observed during the study periods. The abundance of medusae abruptly increased on May 20 and slowly decreased from June 19. Maximum abundance was 0.10 ind. $\mathrm{m}^{-2}$ on June 6. Mature medusae were first observed on June 19, and full maturity of medusae (100\%) was attained on July 31. The sex ratio of matured medusae was almost the same.

Table 1 shows the number of sexually produced eggs, planulae, settled polyps and frustules as well as the settlement ratio of Scolionema suvaense. The total number of eggs and planulae was 819 and that of polyps and frustules was 336 . The total settlement ratio of polyps and frustules was $41.03 \%$ with those of polyps and frustules being $5.62 \%$ and $35.41 \%$, respectively.

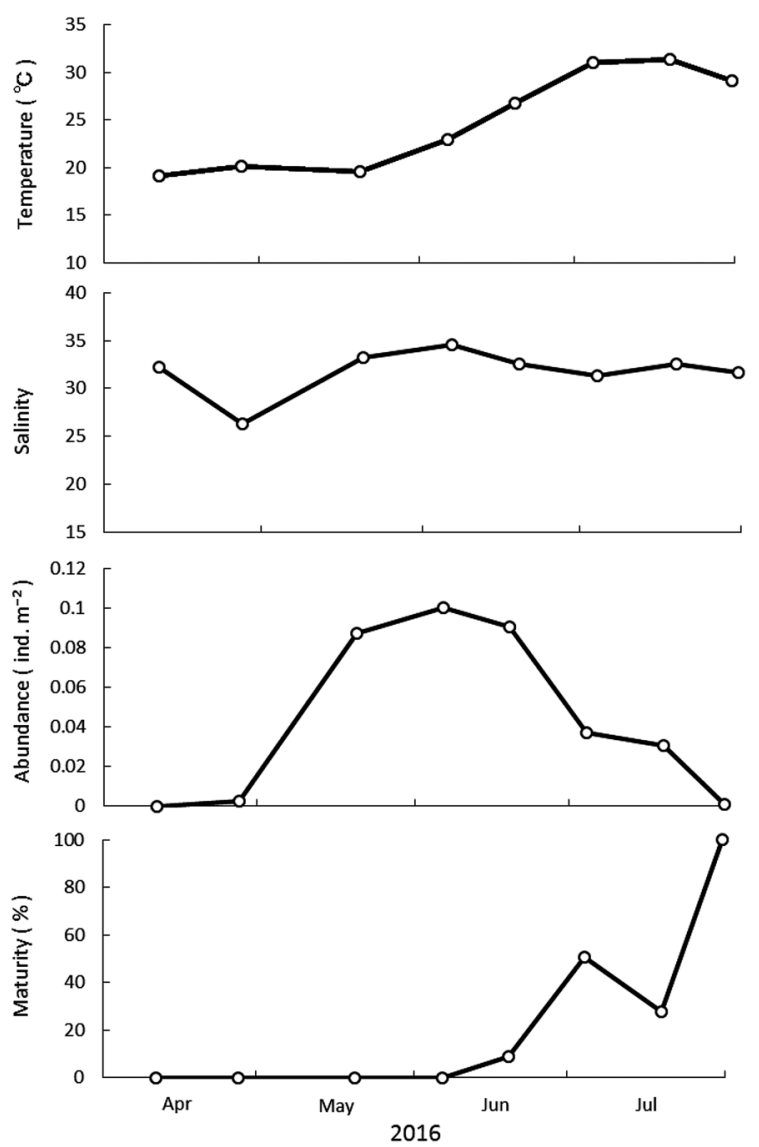

Fig. 2. Surface temperature, salinity, abundance, and maturity of Scolionema suvaense medusae from April 11 to July 31, 2016 in Nagai. 


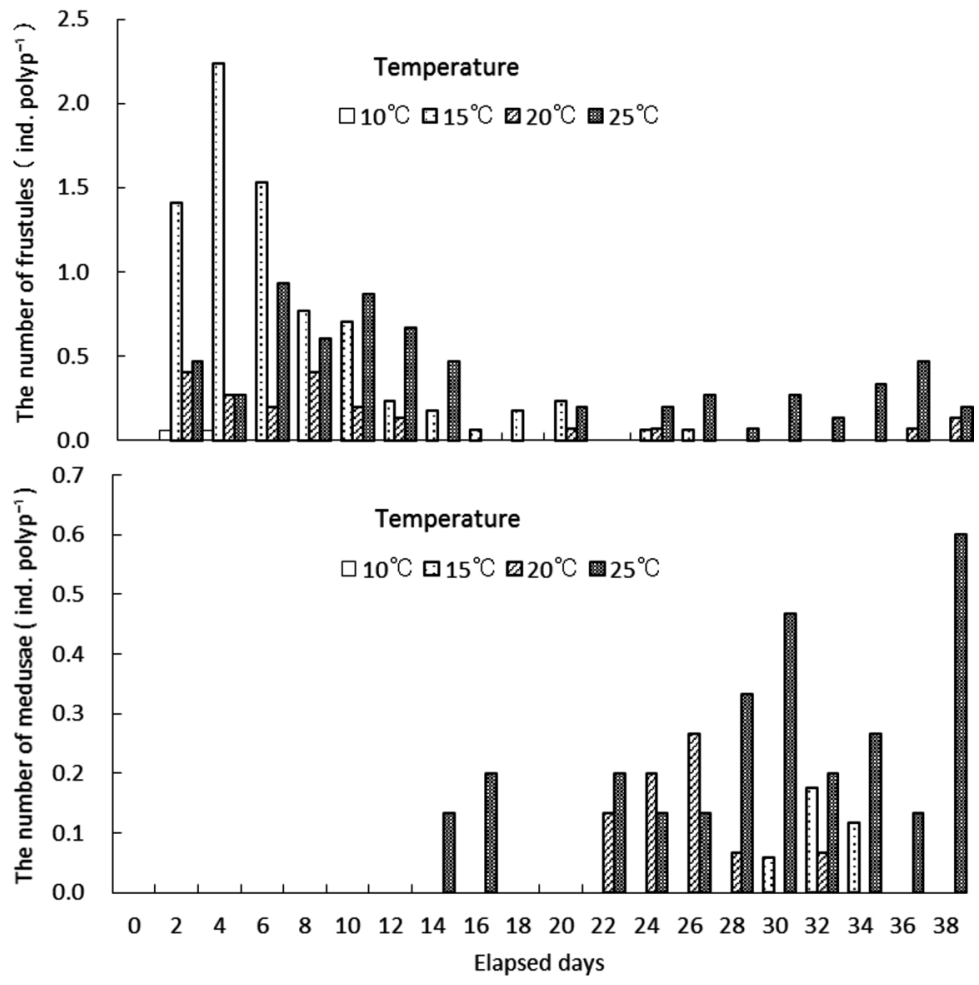

Fig. 3. The number of frustules and medusae produced from Scolionema suvaense polyps at each temperature during the 38 days of incubation.

Table 1. The number of sexually reproduced eggs, planulae, settled polyps and frustules of Scolionema suvaense. Settlement ratios of polyps and frustules are also indicated.

\begin{tabular}{|c|c|c|c|c|}
\hline & \multirow{2}{*}{$\begin{array}{l}\text { The number of eggs and } \\
\text { planulae (ind.) }\end{array}$} & \multirow{2}{*}{$\begin{array}{c}\text { The number of polyps and } \\
\text { frustules (ind.) }\end{array}$} & \multicolumn{2}{|c|}{ Settlement ratio (\%) } \\
\hline & & & polyps & frustules \\
\hline \multirow{2}{*}{ Total } & \multirow{2}{*}{819} & \multirow{2}{*}{336} & \multicolumn{2}{|c|}{41.03} \\
\hline & & & 5.62 & 35.41 \\
\hline
\end{tabular}

Table 2. The asexual reproduction rates of frustules and medusae, bell diameter of liberated medusae and period having medusa buds on the polyps of Scolionema suvaense at each temperature. No medusa buds were observed at $10^{\circ} \mathrm{C}$. Data are shown as means $\pm \mathrm{SD}$.

\begin{tabular}{ccccc}
\hline & \multicolumn{2}{c}{ Production rate (ind. polyp ${ }^{-1}$ day $\left.^{-1}\right)$} & $\begin{array}{c}\text { Bell diameter of liberated medusa } \\
(\mathrm{mm})\end{array}$ & $\begin{array}{c}\text { Period having medusa bud } \\
(\text { days })\end{array}$ \\
\cline { 2 - 3 } & Frustules & Medusae & - & - \\
$10^{\circ} \mathrm{C}$ & 0.00 & 0.00 & $2.4 \pm 0.2$ & $25.2 \pm 0.8$ \\
$15^{\circ} \mathrm{C}$ & 0.20 & 0.01 & $2.1 \pm 0.1$ & $14.1 \pm 0.7$ \\
$20^{\circ} \mathrm{C}$ & 0.05 & 0.02 & $1.4 \pm 0.1$ & $12.9 \pm 0.5$ \\
$25^{\circ} \mathrm{C}$ & 0.17 & 0.07 & & \\
\hline
\end{tabular}

Figure 3 shows the number of frustules and medusae asexually produced from the polyps of Scolionema $\mathrm{su}$ vaense at each temperature. All polyps survived for the 38 days of the experiment. Most frustules were produced at the beginning of the experiment, but most medusae were produced at the end of the experiment.

Table 2 shows the asexual production rate of frustules and medusae, bell diameter of liberated medusae, and stages with medusa buds on the polyps of Scolionema suvaense at each temperature. The highest production rate of frustules was observed at $15^{\circ} \mathrm{C}$. The number of medusa buds on each polyp increased with increasing temperature. Therefore, by increasing the temperature, the production rate of medusae also increased. The maximum production 


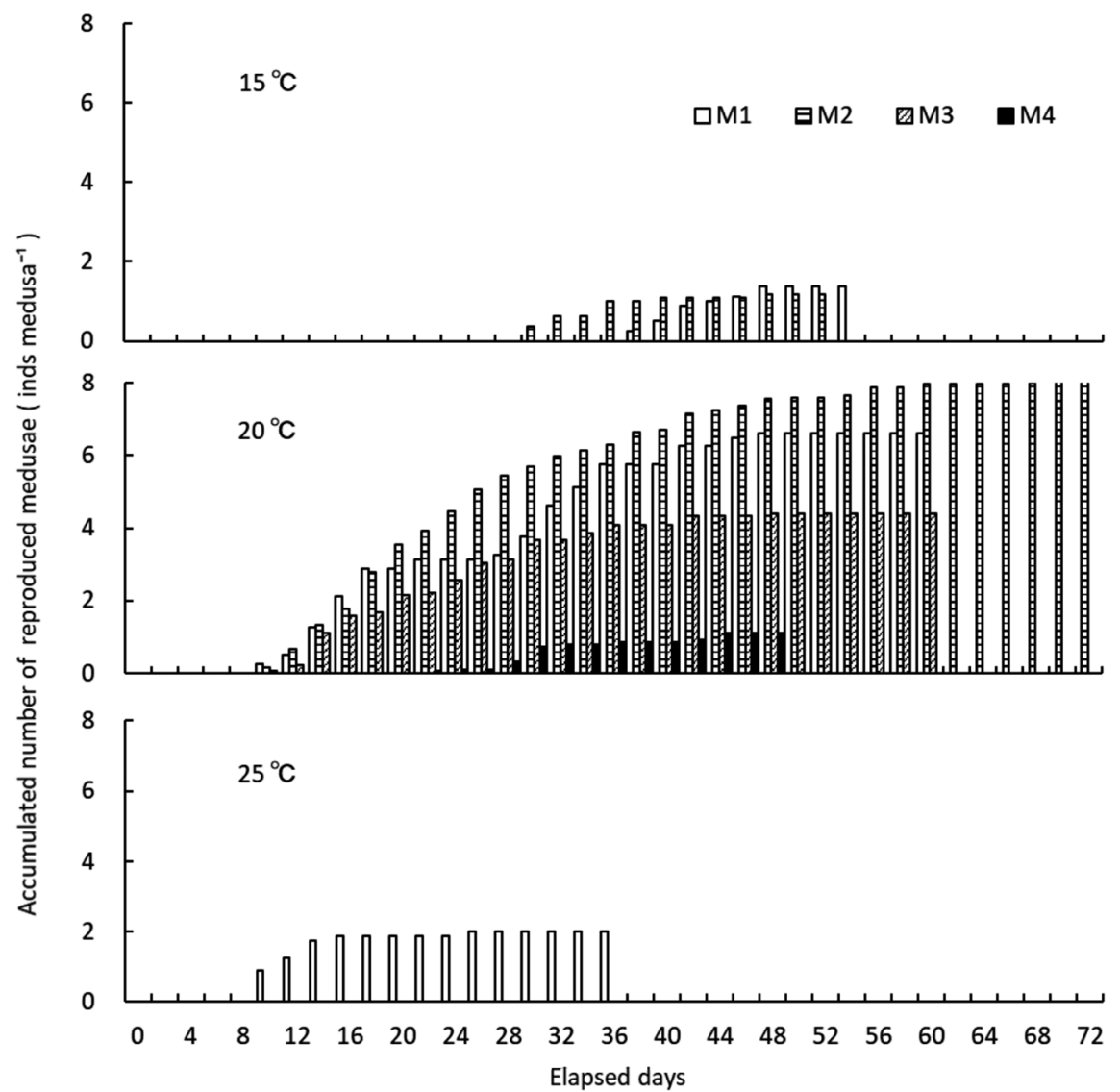

Fig. 4. Changes in the accumulated number of reproduced Scolionema suvaense medusae at each temperature during the incubation experiment.

Table 3. The reproduction rate, survival days, bell diameter and maturity ratio of Scolionema suvaense medusae at each temperature with generation number. Reproduction was not observed in the medusae of the last generation. Data are shown as means \pm SD.

\begin{tabular}{|c|c|c|c|c|c|c|}
\hline & & $\mathrm{N}$ & $\begin{array}{c}\text { Reproduction rate } \\
\text { (ind medusa }{ }^{-1} \text { day }^{-1} \text { ) }\end{array}$ & Survival days & Bell diameter $(\mathrm{mm})$ & Maturity ratio $(\%)$ \\
\hline \multirow[t]{3}{*}{$15^{\circ} \mathrm{C}$} & M1 & 8 & 0.028 & $39.5 \pm 15.5$ & $3.1 \pm 0.14$ & 0 \\
\hline & M2 & 11 & 0.029 & $24.0 \pm 19.2$ & $3.0 \pm 0.16$ & 0 \\
\hline & M3 & 13 & - & $13.1 \pm 11.2$ & $2.5 \pm 0.23$ & 0 \\
\hline \multirow[t]{5}{*}{$20^{\circ} \mathrm{C}$} & M1 & 8 & 0.156 & $43.0 \pm 8.3$ & $4.1 \pm 0.14$ & 0 \\
\hline & M2 & 27 & 0.147 & $54.0 \pm 16.3$ & $3.8 \pm 0.09$ & 0 \\
\hline & M3 & 26 & 0.110 & $38.0 \pm 13.7$ & $3.3 \pm 0.07$ & 0 \\
\hline & M4 & 22 & 0.024 & $40.0 \pm 13.2$ & $3.1 \pm 0.09$ & 0 \\
\hline & M5 & 16 & - & $15.0 \pm 7.4$ & $2.3 \pm 0.10$ & 0 \\
\hline \multirow[t]{2}{*}{$25^{\circ} \mathrm{C}$} & M1 & 8 & 0.070 & $26.3 \pm 8.8$ & $3.9 \pm 0.17$ & 100 \\
\hline & M2 & 16 & - & $16.6 \pm 9.0$ & $2.6 \pm 0.24$ & 62.5 \\
\hline
\end{tabular}

rate of medusae was 0.07 ind. polyp ${ }^{-1}$ day $^{-1}$ at $25^{\circ} \mathrm{C}$. By increasing the incubation temperature, the bell diameter of the liberated medusae, as well as stages with medusa buds on the polyps, also decreased (Table 2).

Figure 4 shows the change in the accumulated number of medusae of Scolionema suvaense produced during the experiment at each temperature. Asexually reproduced medusae were first observed at 30 days at $15^{\circ} \mathrm{C}$, and at 10 days at both $20^{\circ} \mathrm{C}$ and $25^{\circ} \mathrm{C}$ from the start of the experiments, respectively. At $15^{\circ} \mathrm{C}$, the number of asexually produced medusae was very few. At $20^{\circ} \mathrm{C}$, the accumulated number of asexually produced medusae, excepting the 4 th generation of medusae (M4) (Fig. 1), increased after 10 days from the start of the experiment, and the accumu- 
lated number of asexually produced medusae continued to increase throughout the experiment period. At $25^{\circ} \mathrm{C}$, the accumulated number of asexually produced medusae increased only at the beginning of the experiment. All medusae were dead after 36 days from the start of the experiment.

Table 3 shows the asexual reproduction rate of medusae, survival in days, bell diameter, and maturity ratio of Scolionema suvaense at each incubation temperature with their generation number. The highest number of generations was observed at $20^{\circ} \mathrm{C}$. The maximum reproduction rate was 0.156 ind. medusa ${ }^{-1}$ day $^{-1}$ in $\mathrm{M} 1$ at $20^{\circ} \mathrm{C}$, and the rates decreased with generations. The shortest survival rates were observed in the last generation at all temperatures. The bell diameter was the largest in M1 and decreased with generations at all temperatures. Sexually matured medusae were only observed at $25^{\circ} \mathrm{C}$. Specifically, the maturity ratio of matured medusae was $100 \%$ in $\mathrm{M} 1$ at $25^{\circ} \mathrm{C}$. No medusa buds were observed in $\mathrm{M} 2$ at $25^{\circ} \mathrm{C}$. Moreover, $62.5 \%$ of M2 medusae directly matured, and residuals died with no growth.

\section{Discussion}

Along the Japanese coast, some jellyfish are found to be living on seaweed and seagrass: Haliclystus tenuis Kishinoue, 1910 (Stauromedusae) (Kishinouye 1910), Cladonema pacificum Naumov, 1955 (Anthomedusae), Gonionemus vertens and Scolionema suvaense (Limnomedusae) (Toyokawa 2003). However, only a few ecological studies have been conducted on jellyfish living on seaweed and seagrass (Uchida 1976) compared with those on planktonic jellyfish such as Aurelia coerulea. In this study, S. suvaense was the most dominant species of jellyfish in the survey area with seagrass. Scolionema suvaense exhibited a characteristic change in population size, showing abrupt increases and decreases. A similar pattern of population dynamics is observed in the tiny planktonic jellyfish Rathkea octopunctata, which produces medusae asexually in the medusa stage (Matsakis \& Conover 1991). Asexual reproduction is considered to induce abrupt increases in population even in the medusa stage.

Conversely, in comparison with planktonic jellyfish, species living on seaweeds and seagrasses such as Scolionema suvaense, lack the opportunity to extend their habitat area. Goy (1973) observed that the planulae of $S$. suvaense only metamorphosed into polyps. However, we observed that the settled planulae metamorphosed not only into polyps but also into frustules, which are motile and benthic. In addition, the settlement rate of frustules was about six times higher than that of the polyps (Table 1). Hence, most of the settled planulae metamorphose into motile frustules (Fig. $5 ; 1 \rightarrow 2$ ). In the benthic stage of $S$. suvaense, motile frustules extend their habitat area. Moreover, in this experiment, most frustules were produced by polyps at a low temperature $\left(15^{\circ} \mathrm{C}\right)($ Table 2$)$. The exten-

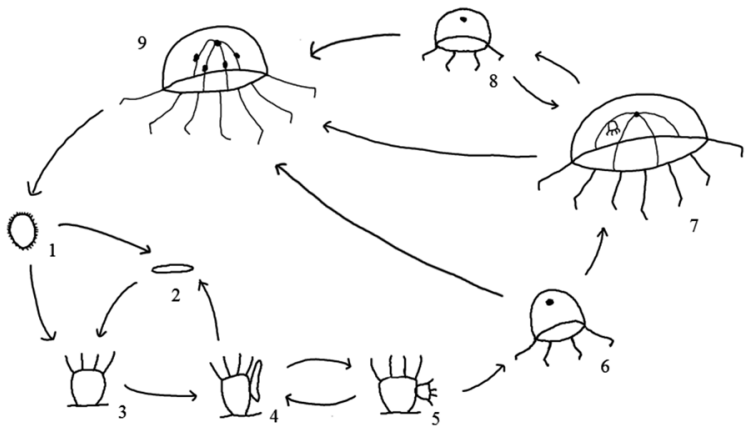

Fig. 5. The life cycle of Scolionema suvaense. (1) Planula, (2) Frustule, (3) Polyp, (4) Polyp with frustule, (5) Polyp with medusa bud, (6) Liberated medusa from polyp, (7) Immature medusa with medusa bud, (8) Liberated medusa from medusa (Daughter medusa), (9) Mature medusa.

sion of habitat area by the frustules occurs during winter and early spring when the temperatures are lower than $15^{\circ} \mathrm{C}$ (Database of the National Research and Development Agency, Japan Fisheries Research and Education Agency).

The reproduction type of Scolionema suvaense changes with increasing temperature. At over $15^{\circ} \mathrm{C}$, in the polyp stage, asexual production of medusae is observed simultaneously with frustule production. With increasing temperature, asexual production rates of the medusae from the polyps also increased. In situ temperature reaches more than $20^{\circ} \mathrm{C}$ in April (Fig. 2). This means that most of the juvenile medusae from polyps will be liberated in spring.

Medusae liberated from polyps rapidly grow, and newly asexually produced medusae are liberated within a short time period (ca. 10 days) at a higher temperature (Fig. 4). However, for M4 medusae, elapsed days until their daughter medusae reproduced was much longer than in the other generations, and the asexual reproduction rate of daughter medusae was apparently low. This suggests that only M1, M2 and M3 generations contribute to the increase in abundance of Scolionema suvaense. Most daughter medusae were observed at $20^{\circ} \mathrm{C}$. Moreover, the reproduction rate of daughter medusae was higher than that of medusae from polyps at $20^{\circ} \mathrm{C}$ in this study. In situ, the abrupt increase in the medusa population between May and June is suggested to be induced by an increase in temperature and depends on the asexual reproduction of daughter medusae. However, reduction of the population of $S$. suvaense will occur, if the asexual reproductive season is prolonged because the number of actively reproducing medusae is reduced with increasing generations.

At over $25^{\circ} \mathrm{C}$, the reproduction rate of daughter medusae abruptly decreased, despite continual asexual reproduction of medusae from polyps (Table 2, 3). Hence, in situ abundance of medusae also decreased. Changes in the field population correlate with decreases in the number of asexually produced medusa in the experiments. At $25^{\circ} \mathrm{C}$, instead of asexual reproduction, sexual reproduction and gonad development were observed. Gonad development 
was not observed for the larger medusae incubated at $20^{\circ} \mathrm{C}$. Therefore, gonad development of Scolionema suvaense is dependent not on growth but on temperature. Previously it was believed that this species could change their reproduction type from asexual to sexual in the medusa stage with temperature changes. Moreover, asexual reproduction is not observed in medusae in $\mathrm{M} 2$ at $25^{\circ} \mathrm{C}$, and their gonads have directly matured for sexual reproduction (Fig. 5 ; $6 \rightarrow 9$ ). In $S$. suvaense, which exhibits different asexual reproduction types, sexual reproduction is very important because it contributes to genetic diversity. This changing from asexual to sexual reproduction at over $25^{\circ} \mathrm{C}$ was consistent with the observations in the field, wherein an increase in the number of matured medusae was followed by disappearance of medusae during June and July.

Changes in the abundance of medusae, such as Aurelia coerulea, usually depend on asexual reproduction during the polyp stage (Watanabe \& Ishii 2001). However, the mass occurrence of medusae in Scolionema suvaense depends on the asexual reproduction by the medusae, which is a distinct characteristic of this species, as well as other hydromedusae such as Rathkea octopunctata (Berrill 1952), Eucheilota paradoxica (Carré \& Carré 1990) and so on. In addition, in this study, the population dynamics of medusae in S. suvaense was dependent on the temperature. Furthermore, most planulae metamorphosed into motile frustules to extend their habitat area. This study is the first to report the findings on seasonal population dynamics related to temperature in the jellyfish $S$. suvaense living on seaweed and seagrass. In the future, we will investigate the inter-annual changes in this population and compare the results with those obtained for other $S$. suvaense living pelagically.

\section{Acknowledgements}

We are grateful to Ms. S. Nakai (Sumida Aquarium) for her significant advice. Helpful assistance was provided by Nagai Fisheries.

\section{References}

Berrill N. J. (1952) Growth and form in gymnoblastic hydroids. II. Sexual and asexual reproduction in Rathkea. J Morph 90: $1-32$.

Carré D, Carré C (1990) Complex reproductive cycle in Eucheilota paradoxica (Hydrozoa: Leptomedusae): medusae, polyps and frustules produced from medusa stage. Mar Biol 104: 303-310.

Chaplygina SF, Dautova TN (2005) Finding of the hydromedusa Hydractinia minima (Trinci, 1903) (Cnidaria: Hydrozoa: Hydractiniidae) in Peter the Great Bay, Sea of Japan. Russian J Mar Biol 31: 141-145
Goy J (1973) Gonionemus suvaensis: structural characters, developmental stages and ecology. Publ Seto Mar Biol Lab 20: 525-536.

Kawamura M, Kubota S (2005) First occurrence of Euphysora gemmifera (Cnidaria, Hydrozoa, Corymorphidae) in Japan. Biogeography 7: 31-33.

Kawamura M, Kubota S (2008) Influences of temperature and salinity on asexual budding by hydromedusa Proboscidactyla ornata (Cnidaria: Hydrozoa: Proboscidactylidae) J Mar Biol Ass UK 88: 1601-1606.

Kishinoue K (1910) Some medusae of Japanese waters. J Coll Sci, Imp Univ Tokyo 27: 1-35.

Kubota S (1993) Resting stage and newly hatched hydroid of a cool water hydrozoan species Climacocodon ikarii Uchida (Hydrozoa, Margelopsidae). Publ Seto Mar Biol Lab 36: 8587.

Matsakis S, Conover RJ (1991) Abundance and feeding of medusae and their potential impact as predators on other zooplankton in Bedford Basin (Nova Scotia, Canada) during spring. Can J Fish Aquat Sci 48: 1419-1430.

Matthews DC (1966) A comparative study of Craspedacusta sowerbyi and Calpasoma dactyloptera life cycles. Pac Sci 20: 246-259

Möller H (1980) Population dynamics of Aurelia aurita medusae in Kiel Bight, Germany (FRG). Mar Biol 60: 123-128.

Omori M, Ishii H, Fujinaga A (1995) Life history strategy of Aurelia aurita (Cnidaria, Scyphomedusae) and its impact on the zooplankton community of Tokyo Bay. ICES J Mar Sci 52: 597-603.

Stretch JJ, King JM (1980) Direct fission: an undescribed reproductive method in hydromedusae. Bull Mar Sci 30: 522-526.

Sugiura Y (1973) On the polyp and medeusa of the hydromedusa, Gastroblasta chengshanensis Ling. Publ Seto Mar Biol Lab 20: 209-220.

Toshino S (2017) Scolionema sanshin sp. n., a new species (Hydrozoa, Limnomedusae, Olindiidae) from the Ryukyu Archipelago, southern Japan. Zootaxa 4344: 277-290.

Toyokawa M (2003) Kaginotekurage no dokusei bunpuseitai no kaimei to bunrui seikatsushi no saikentou. Current Research Activities NRIFS 1: 65. (in Japanese)

Uchida T (1976) A new sporozoan-like reproduction in the hydromedusa, Gonionemus vertens. Proc Japan Acad 52: 387388.

Uchida T, Sugiura Y (1975) On the formation of medusa buds in Proboscidactyla ornata. Publ Seto Mar Biol Lab 22: 347-354.

Uchida T, Sugiura Y (1976) On the medusa-budding found in a limnomedusa, Scolionema suvaense. J Fac Sci Hokkaido Univ Ser VI Zool 20: 600-604.

Uchida T, Sugiura Y (1977) On medusa-budding in the Anthomedusa, Podocoryne minima (Trinci). Publ Seto Mar Biol Lab 24: 53-57.

Watanabe T, Ishii H (2001) In situ estimation of ephyrae liberated from polyps of Aurelia aurita using settling plates in Tokyo Bay, Japan. Hydrobiologia 451: 247-258. 